\title{
ABSTRAK \\ HUBUNGAN INTELLIGENCE QUOTIENT (IQ) TERHADAP CAPAIAN PRESTASI BELAJAR BIOLOGI SMA KOTA MEDAN
}

Anggi Tias Pratama dan Aloysius Duran Corebima, Mahasiswa Pascasarjana Pendidikan Biologi Universitas Negeri Malang, Indonesia dan Fakultas Matematika dan Ilmu Pengetahuan Alam, Universitas Negeri Malang, Indonesia

Hasil penelitian ini menunjukkan bahwa ada hubungan kecerdasan (IQ) dengan prestasi belajar dengan persamaan regersi $\mathrm{y}=-11,587+0,882 \mathrm{x}, \mathrm{F}=324,490$, sig $=0,000$. Hasil analisis $\mathrm{R}$ square IQ memberikan sumbangan sebesar 57,7\% terhadap prestasi belajar biologi. Penelitian ini memberikan sumbangan bahwa IQ memiliki sumbangan yang besar dalam prestasi belajar biologi siswa SMA Kota Medan.

Kata Kunci : Kecerdasan Intelektual (IQ), dan prestasi belajar biologi

Kecerdasan adalah faktor dasar yang memprediksi prestasi akademik di sekolah dan merupakan peran penting dalam mempengaruhi sukses siswa di masa depan (Kuncel, Hezlett, \& Ones, 2004; Chamorro-Premuzic \& Furnham,2005). Kecerdasan berperan pada kemampuan siswa untuk menyerap informasi atau pengetahuan baru dan menjadikannya sebagai dasar untuk mengolah masalah serta upaya penyelesaiannya. Kecerdasan erat kaitannya dengan kemampuan kognitif individu seperti berpikir, mengingat, membaca, pembelajaran, pemecahan masalah dan penggunaan bahasa (Binet, 1905; Zeidner, 1995; Zenderland, 1998). Kecerdasan dapat diukur dengan menggunakan alat psikometri yang biasa disebut sebagai tes kecerdasan intlektual (IQ).

Kecerdasan intelektual (IQ) adalah istilah umum yang digunakan untuk menjelaskan sifat pikiran yang mencakup sejumlah kemampuan, seperti kemampuan menalar, merencanakan, memecahkan masalah, berpikir abstrak, memahami gagasan, menggunakan bahasa, dan belajar. IQ merupakan kemampuan individu untuk memberikan respon yang tepat terhadap stimulus yang diterima Thorndike (1911; 1923). Kemampuan tersebut kemudian dijabarkan secara lebih spesifik oleh Binet (Binet \& Simon, 1916; Varon, 1963) bahwa inteligensi mempunyai tiga elemen berbeda, yaitu direction, adaptation, dan criticsim. Direction akan melibatkan pengetahuan mengenai tentang apa yang harus dilakukan dan bagaimana cara 
melakukannya. Adaptation, mengacu pada upaya membangun strategi untuk melakukan sebuah tugas, selanjutnya berusaha untuk tetap dalam strategi tersebut dan mengadaptasinya saat mengimplementasikannya. Dan criticsm adalah kemampuan untuk mengkritisi pikiran dan tindakan sendiri. Zeidner (1995) menyatakan bahwa seorang yang memiliki kecerdasan rendah lebih mungkin mengalami frustrasi dalam proses pendidikan, mengembangkan agresif dan sikap impulsif.

Skor IQ digunakan sebagai prediktor yang cukup baik terhadap nilai siswa di sekolah, kinerja, prestasi kerja,pendapatan dan aspek lain yang mempengaruhi kesuksesan dalam hidup (Gottfredson, 2004; Herrnstein \& Murray, 1994). Korelasi ratarata antara nilai IQ dan nilai prestasi belajar 0,5 (Neisser et al., 1996), bervariasi sesuai dengan kebijakan yang digunakan. Siswa yang mendapat nilai tinggi maka skor IQ nya juga tinggi dan begitu juga sebaliknya (Detterman \& Daniel, 1989). Siswa yang memiliki IQ tinggi cenderung tampil lebih baik di sekolah daripada mereka yang memiliki skor IQ yang lebih rendah (Coyle \& Pillow, 2008). Prediksi prestasi akademik merupakan salah satu kebanyakan topik penelitian yang penting (Lazano, Gordilo, \& Perez, 2013).

Faktor yang mempengaruhi prestasi akademik dan kecerdasan mengalami perdebatan yang panjang (Miele, 2002). Shapiro (1998) mengungkapkan bahwa kini orangtua berusaha keras membuat anak-anaknya lebih cerdas atau paling tidak menghasilkan skor IQ yang lebih baik. Orangtua beranggapan bahwa siswa yang memiliki skor IQ tinggi akan lebih berhasil dalam bidang akademik maupun kehidupannya, sehingga mereka berusaha menyediakan kemudahan dan fasilitas sebesar-besarnya agar siswa mereka menjadi cerdas dan membantu anak-anak mereka dalam mengaktualisasikan kemampuan kognitif mereka (Phillipson, 2012). Kecerdasan memiliki hubungan yang signifikan dan kontribusi yang penting dalam kaitannya dengan variabel lain misalnya kurikulum, program studi, guru, karakteristik sekolah, dan lain-lain dalam kinerja sekolah (Naglieri \& Bornstein 2003) dan merupakan hubungan timbal balik. Oleh karena itu prestasi belajar individu perlu diperhatikan oleh pihak sekolah, keluarga maupun siswa itu sendiri. 
Prestasi belajar siswa Sekolah Menengah Atas (SMA) jurusan IPA yang didalamnya terdapat program mata pelajaran biologi. Mata pelajaran tersebut juga manjadi pokok dalam pencapaian prestasi belajar, khususnya prestasi belajar biologi. Prestasi belajar biologi merupakan suatu hasil penilaian terhadap suatu kecakapan nyata yang dimiliki siswa dalam mempelajari materi biologi yang bertujuan untuk mengetahui capaian dan sasaran pembelajaran. Prestasi belajar dinyatakan dalam bentuk angka yang dapat mencerminkan potensi siswa tersebut setelah mengikuti pembelajaran (Sudjana, 2005; Mansur, 2012). Tingkat keberhasilan siswa dalam mempelajari materi pelajaran dapat diukur dalam bentuk skor yang diperoleh dari hasil tes, dan dapat digunakan untuk menilai hasil proses belajar mengajar dalam jangka waktu tertentu.

Keberhasilan siswa dalam penilian pembelajaran sesuai dengan kurikukulum, siswa dituntut agar lebih mampu membangun kecerdasan, pengetahuannya sendiri secara mandiri dan aktif. Siswa diharapkan dan dituntut untuk bersikap, berpikir dan berlaku sesuai dengan tuntutan lingkungannya, serta eksistensinya sebagai seorang siswa, sehingga siswa dapat memandang tatanan dan situasi dengan positif (Kemendikbud, 2013). Hal ini berarti adanya kemampuan mengenal diri sendiri disertai adanya usaha memperoleh citra diri yang stabil, mencegah timbulnya perilaku yang tidak wajar sekaligus menanamkan perilaku positif dalam diri siswa. Adakalanya siswa mengalami kesulitan dalam mengkondisikan sikap, berpikir dan menentukan dirinya secara positif.

Survei terhadap guru-guru di SMA Negeri kota Medan permasalahan pembelajaran biologi yaitu masih rendahnya prestasi belajar siswa ditandai dengan ratarata ketidak tuntasan siswa sebesar 50\%. Guru mengasumsikan bahwa intelligence quotient (IQ) merupakan faktor utama yang mempengaruhi rendahnya prestasi belajar siswa tersebut. Selain itu hasil test IQ di jadikan rujukan untuk menentukan jurusan di sekolah karena intelligence quotient merupakan bekal potensial yang akan memudahkan dalam belajar dan pada gilirannya akan menghasilkan prestasi belajar yang optimal.

Berdasarkan hal tersebut perlu dilakukan penelitian mengenai hubungan intelligence quotient (IQ) dengan capaian prestasi belajar biologi. Penelitian ini bertujuan untuk mengetahui seberapa besar hubungan intelligence quotient (IQ) dengan 
capaian hasil belajar biologi SMA di kota Medan. Penelitian ini adalah untuk menganalisis tingkat intelligence quotient (IQ) dan prestasi belajar biologi siswa kelas X SMA Negeri Kota Medan serta untuk menganalisis ada atau tidaknya hubungan antara tingkat intelligence quotient (IQ) terhadap prestasi belajar mata pelajaran biologi siswa kelas X SMA Negeri Kota Medan.

\section{METODE PENELITIAN}

Penelitian ini menggunakan metode survei dengan pendekatan penelitian kuantitatif korelasional atau ex post facto. Populasi yang digunakan adalah seluruh siswa SMA di Kota Medan dan total sampel dalam penelitian ini berjumlah 240 orang siswa jurusan ilmu pengetahuan alam yang terdiri dari 76 orang laki-laki, dan 164 orang perempuan diskolah yang berbeda dengan range usia antara $14-17$ tahun. Teknik pengambilan data yaitu dengan menggunakan test standar yaitu terdiri dari : Culture Fair Scale Intelligence (CFIT) untuk tes IQ, dan tes untuk prestasi belajar biologi menggunakan pilihan berganda dan essay tes.

Analisis data menggunakan analisis regresi sederhana antara IQ dengan prestasi belajar biologi siswa SMA kota Medan, untuk mengetahui hubungan antara IQ dengan prestasi belajar biologi siswa dengan menggunakan bantuan SPSS for windows. Analisa partial correlation untuk melihat hubungan yang lebih murni antara variabel bebas dengan variabel terikat melalui pengendalian variabel bebas lainnya (Chan, 2003; Soegiyono, 2009).

\section{HASIL PENELITIAN}

Grafik linieritas IQ dengan prestasi belajar biologi menunjukkan garis regresi yang mengarah ke kanan atas. Grafik tersebut menunjukkan adanaya linieritas pada hubungan antara kedua variabel yang dilihat dari Oleh karena itu, dapat dilanjutkan ke uji analisis regresi sederhana. Grafik yang menunjukkan linieritas IQ dengan prestasi belajar biologi ditunjukkan pada gambar 1 


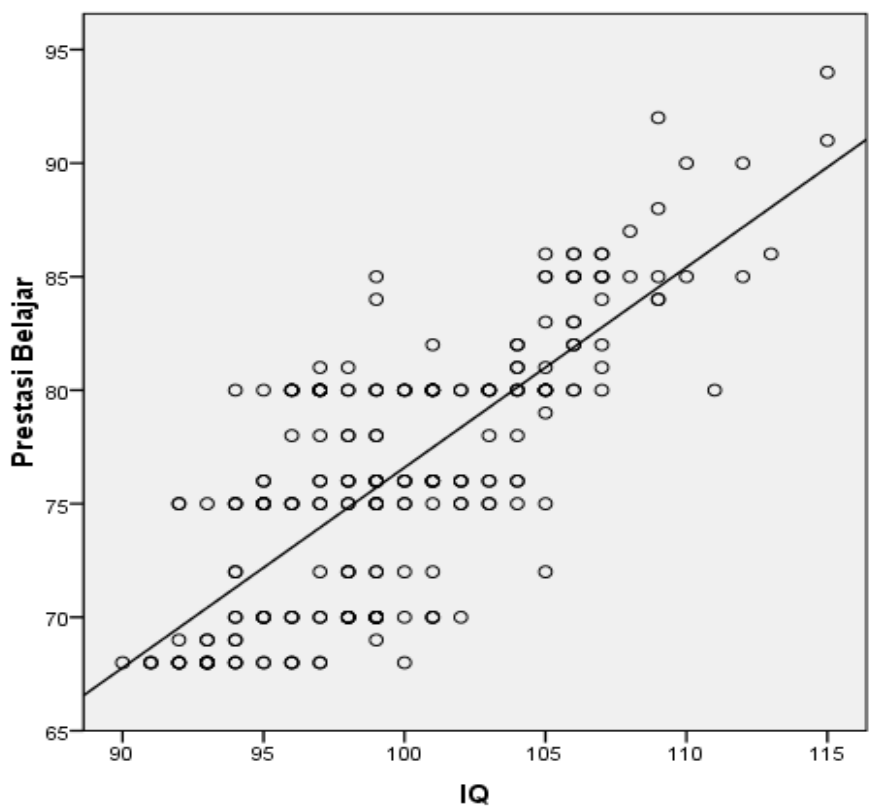

Linear Regression

$\mathrm{R}$ Sq Linear $=0.577$

Gambar 1. Grafik linieritas hubungan statistik data IQ dan prestasi belajar biologi

Pada Tabel 1, 2, dan 3 disajikan ringkasan anava hasil uji statistik data IQ dan prestasi belajar biologi.

Tabel 1. Ringkasan persamaan regresi hubungan IQ dan prestasi belajar biologi

\begin{tabular}{|c|c|c|c|c|}
\hline \multicolumn{5}{|c|}{ Model Summary } \\
\hline Model & $\mathrm{R}$ & R Square & Adjusted R Square & Std. Error of the Estimate \\
\hline 1 & $.760^{\mathrm{a}}$ & .577 & .575 & 3.781 \\
\hline
\end{tabular}

Tabel 2. Koefisien persamaanregresi hubungan IQ dan prestasi belajar biologi

\begin{tabular}{|c|c|c|c|c|c|c|}
\hline \multicolumn{7}{|c|}{ Coefficients $^{\mathbf{a}}$} \\
\hline & \multirow{2}{*}{ Model } & \multicolumn{2}{|c|}{ Unstandardized Coefficients } & $\begin{array}{c}\text { Standardized } \\
\text { Coefficients }\end{array}$ & \multirow[t]{2}{*}{$\mathrm{T}$} & \multirow[t]{2}{*}{ Sig } \\
\hline & & B & Std. Error & Beta & & \\
\hline \multirow[t]{2}{*}{1} & (Constant) & -11.587 & 4.896 & & -2.367 & .019 \\
\hline & IQ & .882 & .049 & .760 & 18.014 & .000 \\
\hline & Dependen & ariable: $\mathrm{P}_{1}$ & Belajar & & & \\
\hline
\end{tabular}

Tabel 3. Ringkasan uji kaji beda persamaan regresi hubungan IQ dengan prestasi belajar biologi

\begin{tabular}{|l|l|c|c|c|c|c|}
\hline \multicolumn{7}{|c|}{ ANOVA $^{\mathbf{b}}$} \\
\hline \multirow{2}{*}{1} & Model & Sum of Squares & Df & Mean Square & F & Sig. \\
\cline { 2 - 8 } & Regression & 4638.119 & 1 & 4638.119 & 324.490 & $.000^{\text {a }}$ \\
\cline { 2 - 8 } & Residual & 3401.864 & 238 & 14.294 & & \\
\hline
\end{tabular}




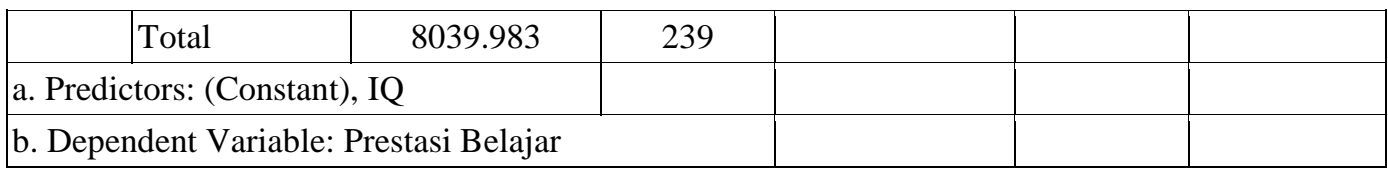

Berdasarkan analisis data Tabel 3 diperoleh nilai $F=324,490$, sig $=0,000$. Analisis Hasil: $\operatorname{sig}=0,000=0 \%<5 \%$ berarti Ho ditolak dan H1 diterima. Jadi persamaan adalah hubungan linier $\mathrm{x}$ dan $\mathrm{y}$ atau $\mathrm{x}$ berpengaruh secara positif terhadap $\mathrm{y}$ (tanda positif diambilkan dari tanda koefisien regresi). Diperoleh nilai $\mathrm{R}$ square atau $\mathrm{R}^{2}$ $=0,577=57,7 \%$, Nilai tersebut menunjukkan bahwa variasi variabel prestasi belajar $(\mathrm{y})$ dapat diterangkan atau dijelaskan oleh variabel IQ (x) sebesar 57,7\%. Dengan perkataan lain variabel x mempengaruhi variabel y sebesar 57,7\%, masih ada 43,3\% variabel y yang dipengaruhi variabel lain selain IQ. Persamaan berdasarkan analisis data tersebut adalah $\mathrm{y}=-11,587+0,882 \mathrm{x} .($ Tabel 2$)$

\section{PEMBAHASAN}

Hasil uji anava menunjukkan bahwa ada hubungan IQ dengan prestasi belajar biologi dengan indeks korelasi 0,577. Hasil penelitian ini sejalan dengan yang dilaporkan oleh Deary (2007) bahwa kecerdasan berhubungan dengan prestasi belajar sebesar 0,81 dan berkontribusi positif terhadap 25 mata pelajaran. Selain itu, Muammar (2011) dengan subjek siswa gifted juga menunjukkan hubungan yang sangat signifikan antara kecerdasan dengan prestasi belajar. Hubungan antara IQ siswa dan prestasi akademik disekolah bervariasi sesuai dengan tingkat perkembangan dan mata pelajaran (Kytala dan Lehto 2008; Strenze 2007; Taub et al. 2008). Perbedaan variasi antara kemampuan kognitif mereka dengan prestasi akademik tergantung pada penilaian (Phillipson, 2012).

Prestasi belajar kognitif yang dimaksudkan dalam penelitian ini adalah hasil belajar ranah kognitif menurut Bloom yang direvisi oleh Anderson dan Krathwohl seperti yang dipaparkan di atas meliputi : mengingat, memahami, menerapkan, menganalisis, mengevaluasi, dan mencipta. Selanjutnya dalam perkembangannya, subsub ranah kognitif menurut Bloom itu direvisi menjadi mengingat, pemahaman, aplikasi, analisis, evaluasi, dan mencipta (Anderson \& Krathwohl, 2001). Prestasi 
belajar merupakan hasil penilaian pendidik terhadap proses belajar dan hasil belajar siswa atau juga kemampuan-kemampuan yang dimiliki siswa setelah siswa menerima pengalaman belajarnya, penilaian tersebut dilakukan untuk menentukan seberapa jauh proses belajar dan hasil belajar siswa telah sesuai dengan tujuan instruksional yang sudah ditetapkan, baik menurut aspek isi maupun aspek perilaku (Winkel, 2004; Sudjana, 2006). Dapat disimpulkan bahwa prestasi belajar adalah hasil penilaian pendidik terha-dap proses dan hasil belajar siswa, yang menggambarkan penguasaan siswa atas materi pelajaran atau perilaku yang relatif menetap sebagai akibat adanya proses belajar yang dialami siswa dalam jangka waktu tertentu yang ditunjukkan dengan nilai tes.

Hasil perhitungan hipotesis penelitian ini menunjukkan bahwa $\mathrm{F}=324,490$, sig $=$ 0,000 terdapat korelasi positif antara skor IQ dengan prestasi belajar kognitif biologi, dimana semakin tinggi skor IQ siswa maka semakin baik nilai prestasi belajar kogitif biologi siswa. Sebaliknya, semakin rendah skor IQ siswa maka semakin rendah pula nilai prestasi belajar kogitif biologi siswa. Hal ini sejalan dengan sejumlah penelitian secara konsisten melaporkan korelasi yang positif antara kecerdasan dan kapasitas kerja ingatan (Ackerman, Beier, \& Boyle, 2005; Colom,Abad, Quiroga, Shih, \& FloresMendoza, 2008; Conway, Kane, \&Engle, 2003; Oberauer, Süß, Wilhelm, \& Wittmann, 2008; Shelton, Elliot, Hill, Calania, \& Gouvier, 2009) yang mendukung prestasi siswa.

Hasil analisis $\mathrm{R}$ square penelitian ini menunjukkan bahwa sumbangan yang diberikan oleh variabel x (IQ) sebesar 57,7\%. Hal ini berarti IQ memiliki sumbangan yang besar dalam menentukan prestasi belajar siswa. Berdasarkan besarnya sumbangan yang diberikan taraf kecerdasan intelektual (IQ) ini sangat mempengaruhi prestasi belajar seorang siswa, di mana siswa yang memiliki taraf inteligensi tinggi mempunyai peluang lebih besar untuk mencapai prestasi belajar yang lebih tinggi. Sebaliknya, siswa yang memiliki taraf inteligensi yang rendah diperkirakan juga akan memiliki prestasi belajar yang rendah. Hal ini sejalan dengan Lanawari (1999), Setiadi (2001), Sulaeman (2008) dan Hendriani (2008) mengemukakan bahwa IQ berhubungan dan berkontribusi terhadap prestasi belajar. Namun bukanlah suatu yang tidak mungkin jika siswa dengan 
taraf inteligensi rendah memiliki prestasi belajar yang tinggi, juga sebaliknya (Winkel, 1997).

Penelitian ini memberikan implikasi praktis kepada sekolah sebagai penyelenggara pendidikan, guru, dan orang tua dalam memahami prestasi belajar terutama untuk memprediksi capaian prestasi belajar. Sesuai dengan hasil penelitian ini diperoleh persamaan regresi $\mathrm{y}=-11,587+0,882 \mathrm{x}$, maka dengan persamaan tersebut dapat dijadikan sebagai dasar bahwa kecerdasan dapat memprediksi prestasi belajar siswa. Hal ini sesuai dengan Laidra, et al, (2007) menyatakan bahwa IQ bisa memprediksi prestasi belajar siswa. Vellutino et al., (2003) dan Fuschs, \& Young (2006) menyatakan bahwa pengolahan kognitif yang baik dalam IQ bisa memprediksi keberhasilan siswa.

Kecerdasan intelektual ini terbukti cukup efektif digunakan untuk membangkitkan ide tertentu yang tergantung pada kerja ingatan (Nusbaum \& Silvia, 2011b). Kecerdasan tidak hanya diartikan secara sempit sebagai kemampuan intelektual, dan berpikir yang berhubungan dengan prestasi belajar biologi siswa disekolah. Ada faktor lain yang berhubungan dengan prestasi belajar biologi siswa di sekolah. Berdasarkan penelitian ini terdapat $42,3 \%$ faktor lain yang berhubungan dengan prestasi belajar biologi yang masih belum terungkap yang tidak diteliti.

IQ tidak dapat berfungsi dengan baik tanpa partisipasi penghayatan dari emosional terhadap mata pelajaran yang disampaikan di sekolah. Menurut Goleman (1995) kontribusi IQ bagi keberhasilan seseorang hanya 20\% dan sisanya $80 \%$ diantaranya adalah emosi. Pendidikan di sekolah oleh guru bukan hanya mengembangkan pada kecerdasan intelektual (IQ) saja, melainkan juga harus mengembangkan kecerdasan emosional. Kecerdasan emosional mengacu pada informasi emosional yang berkaitan dengan persepsi, asimilasi, ekspresi, regulasi dan manajemen (Mayer and Cobb, 2000; Mayer, Salovey and Caruso, 2006). Emosi bisa menuntun kita menghadapi saat-saat kritis dan tugas-tugas yang terlampau banyak bila hanya diserahkan kepada otak. Setiap emosi menawarkan pola persiapan tindakan tersendiri; masing-masing menuntuk ke arah yang telah berjalan dengan baik. 
Selain aspek kecerdasan emosional, aspek kreativitas juga memberikan peranan dalam pencapaian prestasi belajar (McCabe, 1991; Gras et al., 2010). Siswa yang memiliki kreativitas adalah siswa yang memiliki rasa ingin tahu yang besar, sering mengajukan pertanyaan, berani dalam menerima tantangan yang diberikan oleh guru, memberikan gagasan, usul serta menyatakan pendapatnya. Selain itu, siswa yang kreatif juga mempunyai daya imajinasi yang tinggi dan kemampuan dalam mengungkapkan gagasan serta memecahkan masalah (Hirsh, \&Peterson, 2008). Guru juga harus mengoptimalkan kreativitas siswa di sekolah. Sejalan dengan penelitian yang dilakukan Firmanto (2013) dan Benedek et al., (2014) bahwa kreativitas dapat memberikan kontribusi yang kuat dalam prestasi belajar.

Dengan mengetahui prestasi belajar siswa, guru dapat menyatakan kedudukannya dalam kelas, apakah termasuk siswa yang pandai, sedang, atau kurang. Biasanya prestasi belajar dinyatakan dengan angka, huruf atau kalimat dan dicapai pada periode-periode tertentu. Prestasi belajar dapat memberikan kepuasan kepada orang yang bersangkutan, khususnya orang yang sedang menuntut ilmu di sekolah. Sehingga perlu untuk memperhatikan faktor-faktor yang berperan dalam pencapaian prestasi tersebut, salah satunya adalah faktor kecerdasan intelektual yang merupakan faktor dasar atau internal pada individu.

\section{KESIMPULAN}

Kesimpulan penelitian ini adalah variabel kecerdasan intelektual (IQ) memiliki hubungan yang kuat dan memberikan kontribusi dalam prestasi belajar biologi SMA Kota Medan sebesar 57,7\% ( $\mathrm{F}=324,490, \mathrm{p}=0,000)$. Capaian prestasi belajar dapat diprediksi kan dengan mempertimbangkan aspek kecerdasan intelektual, dan masih ada terdapat $42,3 \%$ faktor lain yang berhubungan dengan capaian prestasi belajar biologi siswa yang masih belum terungkap dalam penelitian ini diantaranya yaitu kecerdasan emosional dan kreativitas siswa yang harus dioptimalkan oleh guru di sekolah. 


\section{SARAN}

Berdasarkan hasil penelitian, maka disarankan kepada sekolah dan guru biologi agar memperhatikan faktor IQ untuk dapat disesuaikan dengan perencanaan mengajar yang baik untuk dapat menentukan capaian prestasi belajar biologi yang baik. Bagi orang tua siswa dan masyarakat agar lebih memperhatikan perkembangan anakanaknya, karena jika anak hanya diberi materi berlimpah tanpa perhatian yang cukup dari orang tua maka semua akan kurang bermanfaat bagi perkembangan anak tersebut. Selain itu masih ada faktor lain yang mempengaruhi prestasi belajar biologi siswa yang akan diteli selanjutnya yaitu kecerdasan emosional dan kreativitas siswa.

Dalam penelitian ini perlu dipertimbangkan faktor eksternal yang turut berpengaruh pada capaian prestasi belajar. Proses yang terjadi diluar siswa perlu dicermati bahkan diarahkan menjadi faktor pendukung, antara lain adalah interaksi edukasi yang merupakan inti dari proses belajar mengajar. Upaya tersebut dapat diwujudkan sebagai pendidikan karakter yang bertujuan menjadikan siswa sebagai insan yang cerdas, kreatif, mandiri, bertanggungjawab dan berbudi pekerti.

\section{DAFTAR RUJUKAN}

Anderson, L.W. \& Krathwohl, D.R. (Ed). 2001. A Taxonomy for Learning, Teaching, Assessing (Revision of Bloom's Taxonomy of Education Objectives). AddisonWesley Longman, Inc. New York

Ackerman, P. L., Beier, M. E., \& Boyle, M. O. 2005. Working memory and intelligence: The same or different constructs? Psychological Bulletin, 131,30-60.

Benedek, M., Emanuel, J., Markus, S., Martin, A., \& Aljoscha, C.N. 2014. Intelligence, creativity, and cognitive control: The Common and differential involvement of executive functions in intelligence and creativity. Intelligence, 46, 73-83.

Binet, A. 1905. New methods for the diagnosis of the intellectual level of subnormals. L'Annee Psychologique, 12,191-244 (Translated in 1916 by E. S. Kite in The Development of Intelligence in Children. Vineland, NJ: Publications of the Training School at Vineland.).

Binet, A ; Simon, Th. 1916. The development of intelligence in children: The BinetSimon Scale. Publications of the Training School at Vineland New Jersey Department of Research No. 11. E. S. Kite (Trans.). Baltimore: Williams \& Wilkins.

Chamorro-Premuzic, T., \& Furnham, A. (2005). Personality and intellectual competence. New Jersey: Lawrence Erlbaum Associates.

Chan, Y. H. (2003). Biostatistics 104: Correlational analysis. Singapore Medical Journal, 44 (12), 614-619. 
Colom, R., Abad, F. J., Quiroga, M. A., Shih, P. C., \& Flores-Mendoza, C. (2008).Working memory and intelligence are highly related constructs, but why? Intelligence, 36, 584-606.

Coyle, T. R., \& Pillow, D. R. 2008. SAT and ACT predict GPA after removing $g$. Intelligence, 36, 719-729.

Deary, I. J., Strand, S., Smith, P., \& Fernandes, C. (2007). Intelligence and educational achievement. Intelligence, 35 (1), 13-21.

Detterman, D. K., \& Daniel, M. H. (1989). Correlations of mental tests witheachother and with cognitive variables are highest for low IQ groups. Intelligence, 13, 349359.

Fuchs, D., \& Young, C. L. 2006. On the irrelevance of intelligence in predicting responsiveness to reading instruction. Exceptional Children, 73, 8-30.

Flynn, James R. (2013). Intelligence and Human Progress: The Story of What was Hidden in our Genes (1 ed.). Elsevier Inc.

Goleman, D. 1995. Emotional Intelligence: Why It Can Matter More Than IQ. New York: Bantam Book. A Division of Random House, Inc.

Gras, R. M. L., Bordoy, M., Juste, G., \& Corbalán, J. 2010. Creativity, intelectual abilities and response styles: Implications for academic performance in the secondary school. Evaluation, 26, 212-219

Hendriani. S. 2008. Pengaruh Strategi Belajar, IQ, dan Motivasi Berprestasi terhadap Hasil Belajar Bahasa Inggris Mahasiswa Stain Batusangkar. Ta'dib. 11(1): 80-89

Kaufman, Alan; Lichtenberger, Elizabeth (2002). Assessing adolescent and adult intelligence.

Kanazawa S. 2010. Why Liberals and Atheists Are More Intelligent . Social Psychology Quarterly 73 (1): 33-57.

Kementrian Pendidikan dan Kebudayaan Indonesia. 2013. Implementasi kurikukulum. Jakarta, Kemendikbud.

Kuncel, N. R., Hezlett, S. A., \& Ones, D. S. 2004. Academic performance, career potential, creativity, and job performance: Can one construct predict them all? Journal of Personality and Social Psychology, 86, 148-161.

Kytala, M., \& Lehto, J. E. 2008. Some factors underlying mathematical performance: The role of visuospatial working memory and non-verbal intelligence. European Journal of Psychology of Education, 23, 77-94.

Laidra, K., Pullmann, H., dan Allik, J. 2007. Personality and intelligence as predictors of academic achievement: A crosssectional study from elementary to secondary school. Personality and Individual Differences. 42: 441-451

Lanawati, S. 1999. Hubungan antara Emotional Intelligence dan Intelegensi (IQ) dengan Prestasi Belajar Siswa SMU Methodist di Jakarta. Universitas Indonesia (Tesis). Jakarta

Lozano, J. H., F. Gordilo, \& Pérez, M. A. 2013. Impulsivity, intelligence, and academic performance: Testing the intraction hypothesis. The Spanish Journal Psychology, 15, 922-929. 
Mansur. 2012. Implementasi Penilaian Berbasis Kelas dalam Kurikulum Tingkat Satuan Pendidikan (KTSP). Lembaga Penjaminan Mutu Pendidikan Provinsi Sulawesi Selatan. Makassar.

Mayer, J. D. \& Salovey, P. 2000. What is emotional intelligence. Basic Book. New York

McCabe, M. P. 1991. Influence of creativity and intelligence on academic performance. Journal of Creative Behavior, 25, 116-122. 